\title{
299 閉塞性動脈硬化症における再手術例の検討
}

\section{旭川医科大学 第 1 外科 \\ 堀尾昌司笹嶋唯博和泉裕一察正樹 \\ 久保良彦}

過去 12 年間の教室における下肢閉塞性動脈硬化症 (ASO) に対する再手術例について検討した.

\section{研 究対象}

骨盤型，および骨盤大腿型 ASO 飞対し，織布人工血 管を用いた解剖学的大動脈 (Ao)-腸骨 (I) ・大型 $(F)$ 動脈 bypass 209 例 293 肢を施行した. 内訳は Ao-I bypass 10 肢, Ao-F bypass 175 肢, Ao-F-distal (D) bypass 108 肢. 使用代用血管は, velour knitted $\mathrm{Da}$ cron 269 本, woven Dacron 24 本であった。

さらに，自家静脈 (AVG) を用いた大腿-滕窩脛骨動 脈 bypass 235 肢 (reversed vein bypass (RVB) 117 例 130 肢, In situ vein bypass (ISVB) 96 例 105 肢) そついても検討を加えた，RVB の内訳は大腿㮏简動脈 (膝上) bypass (FPAK) 11 肢, 同 (膝下) bypass (FPBK) 86 肢, 大腿脛骨動脈 bypass (F-tib) 27 肢, 大腿腓骨動脈 bypass (F-per) 6肢. ISVB の内訳は FPAK 2 肢, FPBK 79 肢, F-tib 21 肢, F-per 3 肢 であった。

\section{手 術 成 績}

大動脈-腸骨大腿動脈 by pass graft 全体の 9 年 1 次累 積開存率 $\left(9-1^{\circ} \mathrm{CPR}\right)$ は $73.2 \%, 9$ 年 2 次累積開存率 (9-2 $\left.{ }^{\circ} \mathrm{CPR}\right)$ は $95.7 \%$ でった $(p<0.005\rangle$.なお，吻合 部動脈瘤汇よる graft 異常も graft 閉塞として报った. このなかで, 骨盤大腿型 ASO に対し, 初回 Ao-F bypass のみを施行した群 25 肢 (profundaplasty (PP) 付加 6 肢を含む) と，さらに一期的に D-bypass を加え た群 108 肢を比較すると, Ao-F 単独群では $2-1^{\circ} \mathrm{CPR}^{11}$ が $78.1 \%$ であるのに対し, 一期的 Ao-F-D 群では 2-1 CPR が $97.5 \%$ あり, log rank test にて $p<$ 0.001 の有意差が認められた（図 1 ).

骨盤内 bypass graft 異常の内訳は, graft 閉塞が 11 例 12 肢, 吻合部動脈瘤は中枢吻合部 2 例, 末梢吻合 部 10 例 12 肢であった. Graft 閉塞群では, 原因とし $\tau$ down stream repair (DSR) の不徹底 4 , 病変進行

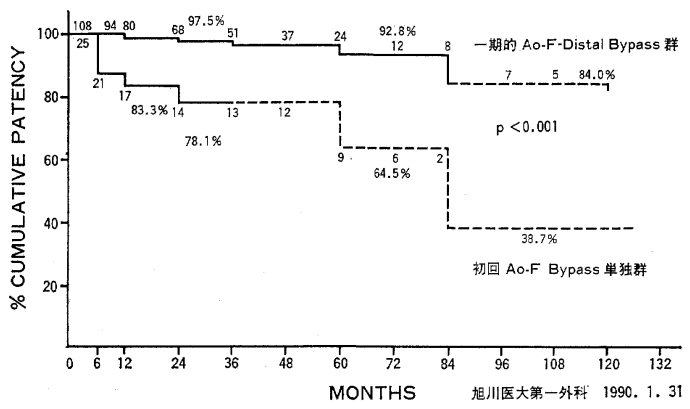

図 1 骨盤大腿型 ASO の一次累積開存率

(PD) 3 ，吻合部内膜肥厚 $(\mathrm{AIH}) 5$ が挙げられ，再手 術 11 肢の内訳は血栓剔除 7 (う亏 2 例任血管内視鏡併 用） (extra anatomic bypass 4 , 付加手術として D. bypass 6 , patch 形成 2 , PP 1 が施行された.

吻合部動脈瘤群では，その原因として DSR 不徹底 4, PD 3, AIH 1 (不明 4) が挙げられ, 再手術術式 では, 全例瘤切除, 人工血管置換が施行され，付加手術 として D-bypass 6,F-F bypass 1 が行われた。

AVG 亿よる大腿-膝窝脛骨動脈 bypass 235 肢につい ての検討では，RVB 130 肢の 6-1 CPR は 74.5\%, 6-2 $2^{\circ} \mathrm{CPR}$ は 89.5\%であった $(p<0.01)$. ISVB 105 肢 の 3-1 $1^{\circ} \mathrm{CPR}$ は $78.9 \% ， 3-2^{\circ} \mathrm{CPR}$ は $94.4 \%$ あった $(p<0.005)$.

早期閉塞は RVB 2 肢 (graft 不良 1 , tunneling 不良 1), ISVB 6 肢 (graft 不良 6 , 弁部血栓 1 ) に生じ た.

晚期 graft 異常では, graft 狭窄が RVB 13 肢, ISVB 9 肢注生じ，そのすべてが術後 3 か力以降 2 年以 内発生していた。 ISVB では, 塞栓症が 3 肢に発生 し, うち 1 肢は瘤様に拡張した静脈弁洞が塞栓源と考元 られた. PD による graft 異常は計 9 肢に発生したが, うち 6 肢が 2 年目以降の発生であった（表 1 ).

Revision 手術は計 47 回施行され, 内訳は, 狭窄部 置換 26 , 中枢側 bypass 追加 10 , 末梢吻合部 jump bypass 6 , patch 形成 5 であった。 
晚期一次 graft 異常

表 1 自家静脈による大腿-膝窩脛骨動脈 bypass

\begin{tabular}{|c|c|c|c|c|c|}
\hline & \multicolumn{2}{|c|}{ Graft 狭窄* } & \multirow{2}{*}{$\begin{array}{l}\text { 塞 栓 } \\
\text { In situ } \\
n=105\end{array}$} & \multicolumn{2}{|c|}{ 病 変進行 } \\
\hline & $\begin{array}{c}\text { Reversed } \\
n=130\end{array}$ & $\begin{array}{l}\text { In situ } \\
n=105\end{array}$ & & $\begin{array}{c}\text { Reversed } \\
n=130 \\
\end{array}$ & $\begin{array}{l}\text { In situ } \\
n=105\end{array}$ \\
\hline $10 \mathrm{wk} \sim 6 \mathrm{mo}$ & 3 & 5 & 1 & & \\
\hline $6 \mathrm{mo} \sim 12 \mathrm{mo}$ & 4 & 1 & & 2 & \\
\hline $1 \mathrm{yr} \sim 2 \mathrm{yr}$ & 6 & 3 & 2 & & 1 \\
\hline $2 \mathrm{yr} \sim 5 \mathrm{yr}$ & & & & 4 & \\
\hline $5 \mathrm{yr} \sim$ & & & & 2 & \\
\hline Total & 13 & 9 & 3 & 8 & 1 \\
\hline
\end{tabular}

* 閉塞例を含む

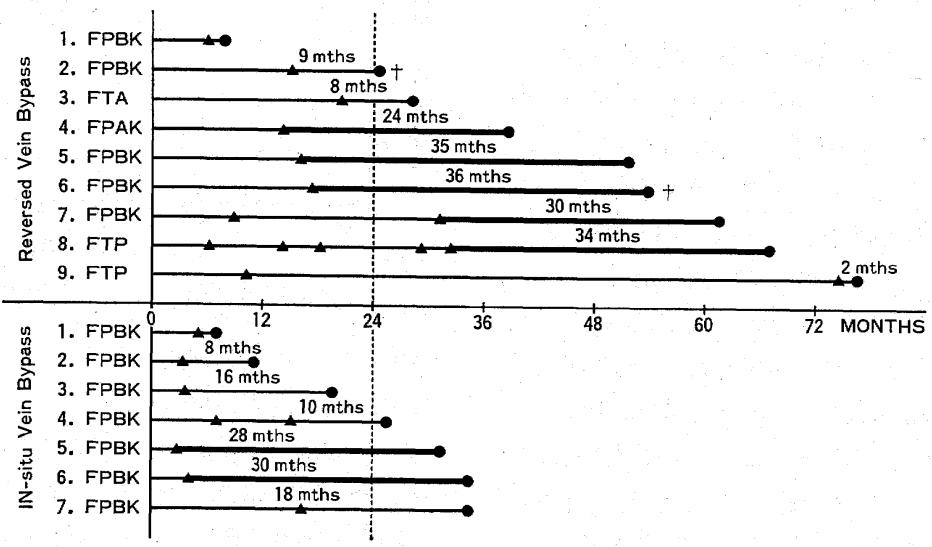

図 2 Graft 狭窄に対する revision 術後の経過

$\Delta$ : revision, - : 開存, ${ }^{\dagger}:$ 死亡, No. mths : 最終 revision 術後経過月数 (太線： 2 年以上経過例)

Revision を数回繰り返した症例も含めて revision 術 後 2 年間をのりきった症例 8 例中，太線に示す 7 例にお いては開存为さらに長期にわたって維持されている（図 2).

\section{考 察}

骨盤大腿型 ASO では, 初回手術時たとえ PP を加え てむ, SFA の閉塞を放置する限り run off は根本的に は改善せず, graft 閉塞や，吻合部への長期にわたる stress による動脈瘤形成に至るむのと考えられる。ゆえ に一期的な DSR の徹底が成績向上のためにきわめて重 要である. AVGでは, ISVB において移植早期の $\mathrm{graft}$ 不良による閉塞が多発し，瘤用弁洞による塞栓症むみら れたが，その理由は saphenous vein (SV) の利用度向 上のために, RVB では置換しているであろう SV segment をそのまま使用したためで, 術式そのものの特徴 ではないと思われる。また，てれらの結果から SV の利 用度については ISVB は RVB に勝るとはいいがたい。
晚期においては，RVB, ISVB と屯に術後 2 年认内の 内膜肥厚 (IH) そよる限局性狭窄が主要な閉塞原因であ り，それらは部分置換により容易に修復可能である。ま た, 初回手術, あるいは revision 術後の 2 年間に IH による狭窄が発生しなければ，graft 閉塞の可能性はほ ぼ消失したと考えられることから, 術後 2 年間の㛜密な follow up により $2^{\circ} \mathrm{CPR}$ の著しい向上が期待できる. 2 年以降は PD に対する check が中心となる.

\section{結 論}

1)骨盤大腿型 ASOに対しては, distal bypass による DSR の徹底が成績向上のためにきわめて重要である.

2) 自家静脈 graft では, graft 狭窄は術後 2 年以内 に発生し, revision 術後 2 年を経過した graft はほぼ 安定化する．したがって，少なくとも最終術後 2 年間は 厳密な follow up を行うべきである.

文 献 1) The Ad Hoc Committee: J. Vasc. Surg. 4: 80, 1986. 